\title{
Enzymatic Reactions in Aqueous-Organic Media VII. Peptide and Ester Synthesis in Organic Solvents by $\alpha$-Chymotrypsin Immobilized through Non-Covalent Binding to Poly(vinyl alcohol)
}

\author{
Hidetaka NORITOMI, Akira WATANABE, and Hideo KISE* \\ Institute of Materials Science, University of Tsukuba, \\ Tsukuba, Ibaraki 305, Japan
}

(Received July 14, 1988)

\begin{abstract}
Chymotrypsin (CT) was immobilized to poly(vinyl alcohol) (PVA) by adsorption from its aqueous solutions. The catalytic activity of CT increased markedly by immobilization for peptide or ester synthesis from $N$-acetyl-L-tyrosine in hydrophilic organic solvents such as acetonitrile or ethanol. The yields of the peptide and ester are strongly dependent on the PVA/CT ratio and water content in the reaction medium. The rate and equilibrium constant of the ester formation reaction are also dependent on water content. These results are discussed in terms of the activation and stabilization of CT in hydrous PVA matrix. The studies on the substrate- and stereo-selectivity for the ester formation reactions suggest that CT maintains its native conformation in PVA matrix. The stability of PVA-immobilized CT is also described.
\end{abstract}

KEY WORDS Peptide Synthesis / Ester Synthesis / $\alpha$-Chymotrypsin / Immobilization / Poly(vinyl alcohol) / Organic Solvent /

During the past decade, enzymatic reactions in organic solvents have been extensively studied to realize organic synthesis with high substrate- and stereoselectivity. However, in general, enzymes are liable to be deactivated by direct contact with organic solvents. In order to overcome this problem, biphasic reaction systems which consist of water and water-immiscible organic solvents have frequently been employed; examples are ester ${ }^{1-11}$ or peptide ${ }^{12-18}$ synthesis by lipase or proteases. In these reaction systems, enzymes were solubilized in aqueous phase or immobilized on hydrophilic supports and therefore considered to be protected from direct contact with organic solvents.

Enzymatic reactions in aqueous solutions with water-miscible organic cosolvents have also been applied to ester or peptide synthesis, but reactions in high concentrations of such hydrophilic organic solvents have mostly been unsuccessful due to deactivation of the enzymes. $^{4,5,8,17,19-23}$ The enzymatic organic synthesis with a variety of substrates and at wide ranges of substrate concentration would be realized if the stability and activity of enzymes were maintained in hydrophilic organic solvents. For this purpose the ester synthesis by $\alpha$-chymotrypsin (CT)-phosphate complexes in various solvents has been extensively studied. ${ }^{24-26}$ Furthermore, a preliminary study on the peptide synthesis by CT immobilized to poly(vinyl alcohol) (PVA) was reported elsewhere. ${ }^{27}$ In the present article, the details of peptide or ester synthesis catalyzed by PVA-immobilized CT in hydrophilic organic solvents are described. The medium effects, especially the effects of the nature

\footnotetext{
* To whom correspondence should be addressed.
} 
of solvents, PVA/enzyme ratio, and water content were investigated to determine optimum conditions for peptide or ester synthesis.

\section{EXPERIMENTAL}

Bovine pancreatic $\alpha$-chymotrypsin (CT) (EC 3.4.21.1, activity $50 \mathrm{U} \mathrm{mg}^{-1}$ ) was purchased from Sigma Chemical Co. $\mathrm{N}$-Acetyl-L-tyrosine (Ac-Tyr-OH), glycinamide hydrochloride, Lalaninamide hydrobromide, L-valinamide hydrochloride, and L-leucinamide hydrochloride were also from Sigma. Poly (vinyl alcohol) (PVA) (degree of polymerization 1500, degree of saponification $86-89 \%$ ) was obtained from Wako Pure Chemical Ind., Ltd. Organic solvents of guaranteed grade or extra pure were obtained from Nakarai Chemical Co. and used without further purification.

The standard reaction for peptide synthesis was carried out as follows: CT $(10 \mathrm{mg})$ was thoroughly mixed with PVA powder $(1.00 \mathrm{~g})$, and then a certain amount of phosphate buffer solution $(0.1 \mathrm{M}, \mathrm{pH} 6.8)$ was added to the mixture. After keeping the mixture standing for about $10 \mathrm{~min}$, Ac-Tyr-OH $(50 \mathrm{mg}$, $0.22 \mathrm{mmol})$ and $\mathrm{Gly}-\mathrm{NH}_{2}(22 \mathrm{mg}, 0.20 \mathrm{mmol})$ in acetonitrile $(20 \mathrm{ml})$ were added. The mixture was incubated with constant reciprocal shaking ( 140 cycle per min) at $30^{\circ} \mathrm{C}$ for $24 \mathrm{~h}$. After the reaction, an aliquot was taken from the reaction mixture and, if necessary, filtered with a polytetrafluoroethylene membrane filter. The amounts of the reaction components were determined with HPLC (Shimadzu LC-6A) using a Shimadzu Shim-pack CLC-ODS column eluted with water-acetonitrile $(50: 50$ by volume). Acetanilide was used as the internal standard.

The esterification of Ac-Tyr-OH in ethanol was carried out by a similar method to that described above, except that pure water was used instead of buffer solution to dissolve CT, and PVA was added to the CT solution. Flasks or vials with flat bottom are desirable for the formation of gellous PVA film containing CT.
The amounts of Ac-Tyr-OH and its ethyl ester Ac-Tyr-OEt were determined with an HPLC (JASCO Tri Rotar SR-1) using a JASCO Finepak SIL C18 column eluted with the same solvent as above. The initial reaction rate was calculated from the amount of Ac-Tyr-OEt formed after $30 \mathrm{~min}$ reaction. The equilibrium constant $K$ for the ester formation was determined from the amount of the reaction components after 5-6 days reaction.

\section{RESULTS AND DISCUSSION}

\section{Peptide Synthesis from Ac-Tyr-OH and Amino Acid Amides}

When a phosphate buffer solution of CT was mixed with a solution of Ac-Tyr-OH and Gly- $\mathrm{NH}_{2}$ hydrochloride in an organic solvent, such as ethanol or acetonitrile, colorless precipitates were formed which were considered complexes of CT and phosphate salts (CTphosphate) ${ }^{25,26.28}$ In these mixtures, CT catalyzed the reaction of Ac-Tyr-OH with Gly$\mathrm{NH}_{2}$ and the yields of Ac-Tyr-Gly- $\mathrm{NH}_{2}$ after $24 \mathrm{~h}$ at $30^{\circ} \mathrm{C}$ are listed in Table I. Among the solvents used, ethanol gave the highest yield of the peptide.

When a buffer solution was added to a mixture of CT and PVA and then the substrate solution was added, the resulting mixture consisted of a clear solution and a gellous PVA. A spectroscopic study revealed that less than $10 \%$ of CT was dissolved in the liquid phase, and the change in the amount of CT in solution was negligible after $24 \mathrm{~h}$ incubation at $30^{\circ} \mathrm{C}$. These results indicate that most of CT was immobilized through non-covalent binding to PVA matrix probably due to hydrophilic interaction between PVA and CT. Thus, in these organic solvents, in which PVA is insoluble, covalent binding ${ }^{29,30}$ or crosslinking $^{31-36}$ are not required to immobilize the enzyme to PVA. The results of the peptide synthesis by PVA-immobilized CT are also shown in Table I. In all the solvents used, especially in acetonitrile and tetrahydrofuran 
Table I. Peptide synthesis from Ac-Tyr-OH and Gly$\mathrm{NH}_{2}$ by CT-phosphate and PVA-immobilized $\mathrm{CT}^{\mathrm{a}}$

\begin{tabular}{lcc}
\hline \multirow{2}{*}{ Solvent } & \multicolumn{2}{c}{ Yield of Ac-Tyr-Gly-NH $\mathrm{N}_{2} / \%$} \\
\cline { 2 - 3 } & CT-Phosphate & PVA-CT \\
\hline Ethanol & 29 & 35 \\
Acetonitrile & 17 & 43 \\
Acetone & 16 & 24 \\
THF & 13 & 39 \\
DMF & 9 & 10 \\
\hline
\end{tabular}

a Ac-Tyr-OH $50 \mathrm{mg}$, Gly- $\mathrm{NH}_{2}$ hydrochloride $22 \mathrm{mg}$, CT $10 \mathrm{mg}$, phosphate buffer $(0.1 \mathrm{M}, \mathrm{pH} 6.8) 1 \mathrm{ml}$, solvent $20 \mathrm{ml}, 30^{\circ} \mathrm{C}, 24 \mathrm{~h}$. Immobilization was done with $1 \mathrm{~g}$ of PVA.

(THF), peptide yields are much higher than those for the reactions without PVA. It may be considered that in the PVA matrix, CT is hydrated enough to maintain its native conformation and catalytic activity. Since in ethanol the peptide formation is competitive with ester formation, the following studies were made using acetonitrile as a solvent in order to avoid complicated side reactions.

Figure 1 shows plots of the yields of the peptide against water content. In these experiments, water content was changed by changing the amount of buffer solution in which CT was dissolved. The peptide yield exhibits strong dependency on water content both for CTphosphate and PVA-immobilized CT. Under anhydrous conditions, peptide formation was totally inhibited, indicating that minimum amounts of water are essential for the activation of CT. At higher concentrations of water, however, peptide yield decreases probably due to the shift of equilibrium to hydrolysis. The maximum yield of the peptide by PVA-immobilized CT was obtained at around $7 \%$ water. At lower water content, the reactions are too slow to reach equilibrium before $24 \mathrm{~h}$, and the change in the peptide yield in Figure 1 is considered the consequence of change in the reaction rate with water content rather than change in the equilibrium constant.

It was found that a PVA/CT ratio larger

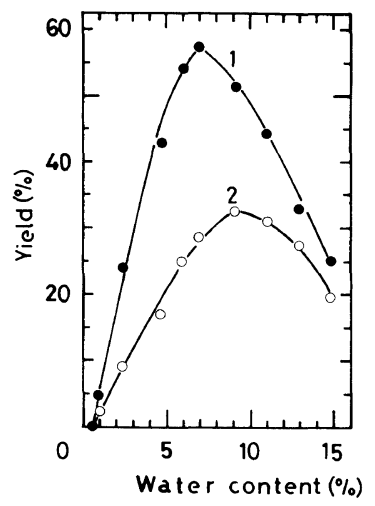

Figure 1. Effect of water content on chymotrypsincatalyzed peptide synthesis. CT $10 \mathrm{mg}$, Ac-Tyr-OH $50 \mathrm{mg}$, Gly- $\mathrm{NH}_{2} \mathrm{HCl} 22 \mathrm{mg}$, acetonitrile $20 \mathrm{ml}, 30^{\circ} \mathrm{C}$, 24 h. 1, PVA (1 g)-immobilized CT; 2, CT-phosphate.

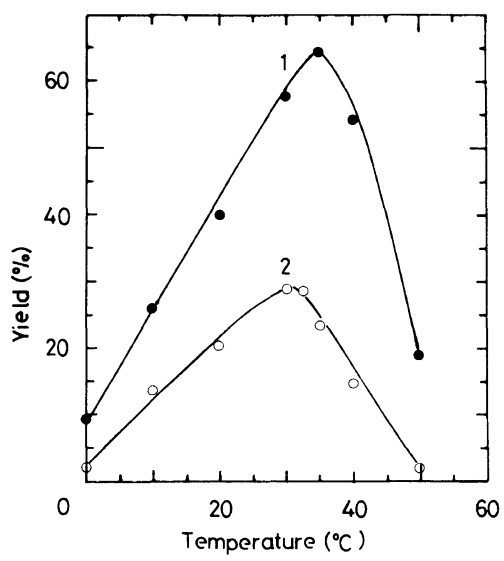

Figure 2. Effect of reaction temperature on peptide synthesis. CT $10 \mathrm{mg}$, Ac-Tyr-OH $50 \mathrm{mg}, \mathrm{Gly}-\mathrm{NH}_{2} \mathrm{HCl}$ $22 \mathrm{mg}$, acetonitrile $20 \mathrm{ml}$, phosphate buffer $1.5 \mathrm{ml}, 24 \mathrm{~h}$. 1, PVA (1 g)-immobilized CT; 2, CT-phosphate.

than 10 was required to enhance the catalytic activity of CT. At lower PVA/CT ratios, a part of CT was suspended in the organic phase. The peptide yield increased with the PVA/CT ratio up to 200 .

The effect of the reaction temperature on the peptide yield is shown in Figure 2. The optimum temperatures are 35 and $30^{\circ} \mathrm{C}$ for reactions with and without PVA, respectively, and in the whole range of temperature studied PVA-immobilized CT gave higher yields of the peptide than PVA-free CT. Above $40^{\circ} \mathrm{C}$, however, the peptide yield sharply decreased 
for both the CTs, although $20 \%$ yield was obtained at $50^{\circ} \mathrm{C}$ by PVA-immobilized CT.

Figure 3 shows plots of the peptide yields against the $\mathrm{pH}$ of the buffer solution. In the presence of a large excess of acetonitrile, the solution was considered not to be buffered, but a certain effect of salt composition in PVA matrix on the peptide formation was expected. Actually, however, the peptide yield by immobilized CT was scarcely affected by $\mathrm{pH}$ (Figure 3). When pure water was used instead of the buffer solution, the peptide yield decreased markedly. At the present stage of the investigation, these results cannot be fully explained, but it is probable that a phosphate salt exhibits a certain influence on the reactivity of glycinamide, since, as will be mentioned later, contrary to a peptide synthesis, pure water is a good co-solvent for CT in the esterification of Ac-Tyr-OH by PVA-immobilized CT.

The results of the reactions of Ac-Tyr-OH with several amine components are summarized in Table II. Only a slight increase in the peptide yield was demonstrated in going from glycinamide to leucinamide for the reactions by immobilized CT, whereas an opposite tendency was found for the reactions without PVA. Fersht et al. ${ }^{37}$ evaluated the ratios of the rate constants in aqueous solutions for the attack of alaninamide and glycinamide to that of $55 \mathrm{M}$ water on Ac-Tyr-chymotrypsin to be 100 and 14, respectively. Although the present data in Table II are not kinetics but rather thermodynamical ones, the apparent selectivity of amine components in peptide formation in acetonitrile seems to be different from that in aqueous solutions. In the present reaction systems, substrate selectivity may be influenced not only by the molecular interaction of the substrate with CT but also by the partition of the substrate between organic phase and PVA matrix where CT is incorporated.

\section{Ester Synthesis from Ac-Tyr-OH and Ethanol}

The esterification of Ac-Tyr-OH was in-

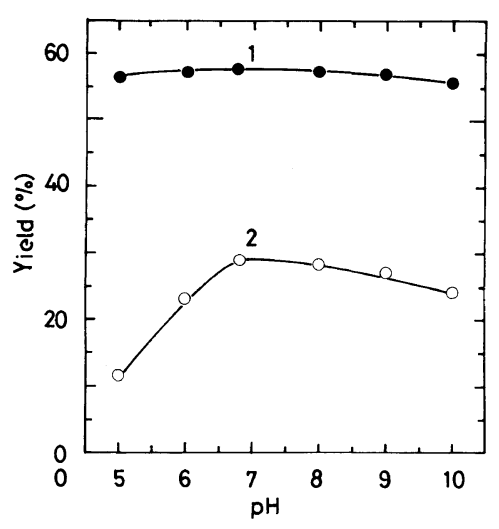

Figure 3. Effect of $\mathrm{pH}$ on peptide synthesis. CT $10 \mathrm{mg}$, Ac-Tyr-OH $50 \mathrm{mg}$, Gly- $\mathrm{NH}_{2} \mathrm{HCl} 22 \mathrm{mg}$, acetonitrile $20 \mathrm{ml}$, phosphate buffer $1.5 \mathrm{ml}, 30^{\circ} \mathrm{C}, 24 \mathrm{~h}$. 1, PVA (1 g)immobilized CT; 2, CT-phosphate.

Table II. Chymotrypsin-catalyzed synthesis of peptides from Ac-Tyr-OH and amino acid amides in acetonitrile ${ }^{a}$

\begin{tabular}{lcc}
\hline \multirow{2}{*}{$\begin{array}{c}\text { Amino acid } \\
\text { amide }\left(\mathrm{A}-\mathrm{NH}_{2}\right)\end{array}$} & \multicolumn{2}{c}{ Yield of Ac-Tyr-A-NH $/ \%$} \\
\cline { 2 - 3 } & CT-Phosphate & PVA-CT \\
\hline Glycinamide & 29 & 58 \\
L-Alaninamide & 26 & 61 \\
L-Valinamide & 25 & 62 \\
L-Leucinamide & 23 & 65 \\
\hline
\end{tabular}

a Ac-Tyr-OH $50 \mathrm{mg}$, equimolar $\mathrm{A}-\mathrm{NH}_{2}$ to $\mathrm{Ac}-\mathrm{Tyr}-\mathrm{OH}$, CT $10 \mathrm{mg}$, phosphate buffer $(0.1 \mathrm{M}, \mathrm{pH} 6.8) 1.5 \mathrm{ml}$, acetonitrile $20 \mathrm{ml}, 30^{\circ} \mathrm{C}, 24 \mathrm{~h}$. Immobilization was done with $1 \mathrm{~g}$ of PVA.

vestigated by PVA-immobilized CT in ethanol. The plots of the initial reaction rate and the yield of the ester (Ac-Tyr-OEt) after $24 \mathrm{~h}$ reaction against the ratio of PVA to $\mathrm{CT}$ are shown in Figure 4. Without PVA, the reaction was very slow and yield of the ester after $24 \mathrm{~h}$ was $21 \%$, but the reaction rate increased markedly by immobilizing CT to PVA. This suggests again that CT is activated by being incorporated into the PVA matrix containing a small amount of water. However, with increase in the PVA/CT ratio higher than 10 , the reaction rate decreased gradually. The ester yield increased at first sharply and then became almost independent of the ratio. In or- 


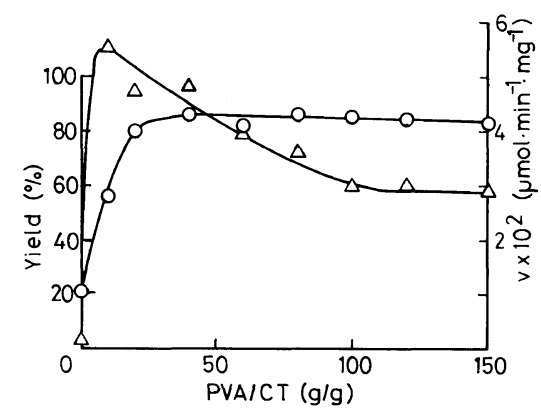

Figure 4. Effect of PVA/CT ratio on ester synthesis. CT $5 \mathrm{mg}$, Ac-Tyr-OH $22 \mathrm{mg}$, ethanol $10 \mathrm{ml}$, water $0.25 \mathrm{ml}, 30^{\circ} \mathrm{C}$. $\triangle$, reaction rate; $\bigcirc$, ester yield after $24 \mathrm{~h}$.

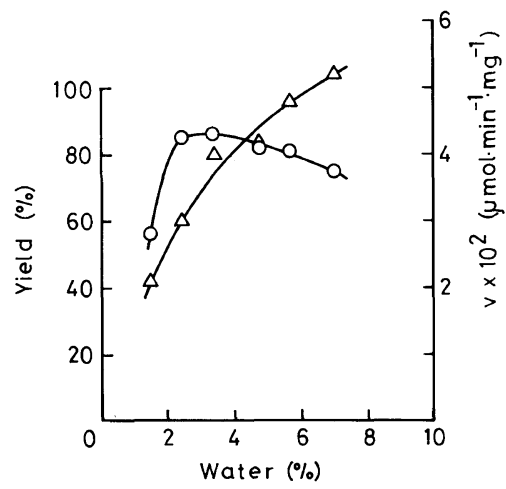

Figure 5. Effect of water content on ester synthesis. CT $5 \mathrm{mg}$, Ac-Tyr-OH $22 \mathrm{mg}$, PVA $0.5 \mathrm{~g}$, ethanol $10 \mathrm{ml}, 30^{\circ} \mathrm{C}$. $\triangle$, reaction rate; $\bigcirc$, ester yield after $24 \mathrm{~h}$.

der to explain these results, the effect of water concentration around $\mathrm{CT}$ must be taken into consideration. As Figure 5 shows, with a constant amount of PVA, the decrease in water content in the reaction mixture led to a decrease in the reaction rate. Therefore, the above dependency of the reaction rate on PVA/CT ratio may be at least partly the consequence of change in water concentration around CT; PVA, which has strong interaction with water, is considered to copmetitively adsorbe water and therefore reduce water concentration around CT. A close inspection of the reaction mixtures revealed that with large amounts of PVA a CT solution was adsorbed into only a part of the added PVA, and excess PVA seemed to incorporate neither water nor CT. This would lead to independency of the

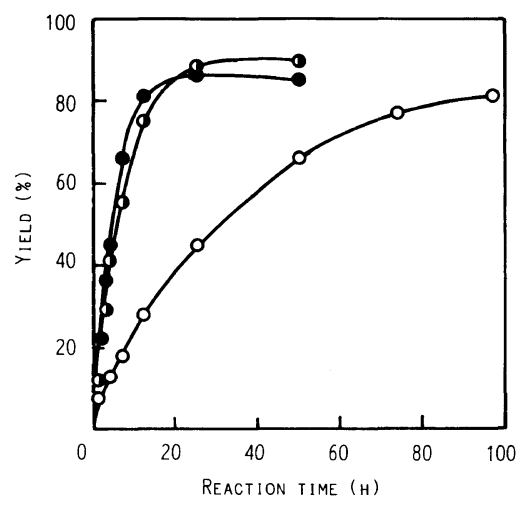

Figure 6. Time course of ester formation reaction. CT $5 \mathrm{mg}$, Ac-Tyr-OH $22 \mathrm{mg}$, PVA $0.5 \mathrm{~g}$, ethanol $10 \mathrm{ml}, 30^{\circ} \mathrm{C}$. Water content: $\bigcirc, 0.125 \mathrm{ml} ; 0.25 \mathrm{ml} ; 0.5 \mathrm{ml}$.

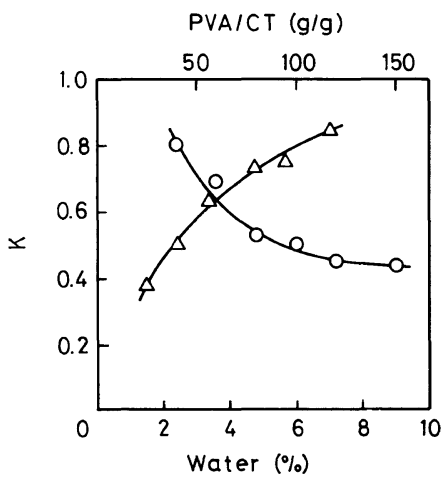

Figure 7. Effect of PVA/CT ratio and water content on the equilibrium constant for ester formation. CT $5 \mathrm{mg}$, Ac-Tyr-OH $22 \mathrm{mg}$, ethanol $10 \mathrm{ml}, 30^{\circ} \mathrm{C}$ : $\bigcirc$, change in PVA-CT; $\triangle$, change in water content.

reaction rate and ester yield from the amount of PVA at high PVA/CT ratios.

The increase in the reaction rate with water content (Figure 5) may be attributed to the increase in the amount of hydrated CT, whereas the decrease in the ester yield at higher water contents is most probably due to the shift of equilibrium to hydrolysis. This situation is very similar to the esterification catalyzed by CT-phosphate salt complexes. $^{25,26}$

The time course of the esterification is shown in Figure 6. It is apparent that at a water content higher than $2.4 \%$, the reaction reaches equilibrium before $24 \mathrm{~h}$. In Figure 
7, the equilibrium constant $K(K=$ [Ac-Try$\left.\mathrm{OEt}]\left[\mathrm{H}_{2} \mathrm{O}\right] /[\mathrm{Ac}-\mathrm{Tyr}-\mathrm{OH}][\mathrm{EtOH}]\right)$ is plotted against PVA/CT ratio and water content under the same conditions as in Figures 4 and 5. Interestingly, $K$ increased with water content, and decreased with PVA/CT ratio. The dependency of $K$ on PVA/CT ratio may be the consequence of the change in water concentration around $\mathrm{CT}$ as mentioned above. These results suggest that change in specific interaction of water with the substrate or product may be at least partially responsible for the change in $K$ with water concentration.

In order to examine the stability of PVAimmobilized CT, consecutive reactions were carried out in which a constant amount $(22 \mathrm{mg})$ of Ac-Tyr-OH was added every $24 \mathrm{~h}$ for 7 days to the reaction mixture containing $5 \mathrm{mg}$ of $\mathrm{CT}$ immobilized to $0.5 \mathrm{~g}$ of PVA in ethanol $(10 \mathrm{ml})$ water $(0.5 \mathrm{ml})$ at $30^{\circ} \mathrm{C}$. The total yields of AcTyr-OEt at every $24 \mathrm{~h}$ were close to the equilibrium yield; this indicates that PVAimmobilized CT maintaines most its initial catalytic activity for at least 7 days in the reaction mixture.

Finally, reactions were carried out with $N$ acetyl-L- and $\mathrm{N}$-acetyl-D-tryptophan as substrates; the former gave the corresponding ester in $84 \%$ yield, whereas the latter did not react at all. Furthermore, $\mathrm{N}$-acetyl-L-alanine and $N$-acetyl-L-leucine failed to give the corresponding esters under the same reaction conditions as for Ac-Tyr-OH. These results clearly indicate that in the present reaction system, CT has strict stereo- and substrateselectivity and that CT-maintains its native conformation in the PVA matrix.

In conclusion, CT can be immobilized into PVA matrix by a simple adsorption method, and the immobilized CT is a stable and efficient catalyst for peptide or ester synthesis from Ac-Tyr-OH in hydrophilic organic solvents. No covalent binding of CT to PVA is required, and this may be an easy and versatile method for the immobilization of enzymes in organic solvents. For peptide or ester synthesis, water content was found to be a primary factor to influence the reaction rate and product yields. The ratio of PVA to CT was also an important factor for controling the reaction, probably through change in water concentration around CT.

\section{REFERENCES}

1. A. M. Klibanov, G. P. Samokhin, K. Martinek, and I. V. Berezin, Biotechnol. Bioeng., 19, 1351 (1977).

2. D. Tarquis, P. Monsan, and G. Durand, Bull. Soc. Chim. Fr., II-76 (1980).

3. K. Martinek, A. Semenov, and I. V. Berezin, Biochim. Biophys. Acta, 658, 76 (1981).

4. J. L. Vidaluc, M. Baboulene, V. Speziale, and A. Lattes, Tetrahedron, 39, 269 (1983).

5. B. Cambou and A. M. Klibanov, Biotechnol. Bioeng., 26, 1449 (1984).

6. B. Cambou and A. M. Klibanov, J. Am. Chem. Soc., 106, 2687 (1984).

7. C. Marlot, G. Langrand, C. Triantaphylides, and J. Baratti, Biotechnol. Lett., 7, 647 (1985).

8. G. Kirchner, M. P. Scollar, and A. M. Klibanov, $J$. Am. Chem. Soc., 107, 7072 (1985).

9. H. H. Weetal, Biotechnol. Bioeng., 27, 124 (1985).

10. M. Reslow, P. Adlercreutz, and B. Mattiasson, Appl. Microb. Biotechnol., 26, 1 (1987).

11. T. Mori, K. Nilsson, P.-O. Larsson, and K. Mosbach, Biotechnol. Lett., 9, 455 (1987).

12. P. Kuhl, A. Konnecke, G. Doring, H. Daumer, and H.-D. Jakubke, Tetrahedron Lett., 21, 893 (1980).

13. P. Kuhl, S. Posselt, and H.-D. Jakubke, Pharmazie, 36, 463 (1981).

14. A. Konnecke, R. Bullerjahn, and H.-D. Jakubke, Monatsh. Chem., 112, 469 (1981).

15. A. N. Semenov, I. V. Berezin, and K. Martinek, Biotechnol. Bioeng., 23, 355 (1981).

16. Yu. L. Khmel'nitski, F. K. Dien, A. N. Semenov, K. Martinek, B. Veruovic, and V. Kubanek, Tetrahedron, 40, 4425 (1984).

17. J. B. West and C.-H. Wong, J. Org. Chem., 51, 2728 (1986).

18. J. R. Matos, J. B. West, and C.-H. Wong, Biotechnol. Lett., 9, 233 (1987).

19. R. G. Ingalls, R. G. Squires, and L. G. Butler, Biotechnol. Bioeng., 17, 1627 (1975).

20. W. P. Vann and H. H. Weetal, J. Solid-Phase Biochem., 1, 297 (1976).

21. G. A. Homandberg, J. A. Mattis, and M. Laskowski, Jr., Biochemistry, 17, 5220 (1978).

22. G. Anderson and P. L. Luisi, Helv. Chim. Acta, 62 , 488 (1979). 
23. K. Nilsson and K. Mosbach, Biotechnol. Bioeng., 26, 1146 (1984).

24. H. Kise and H. Shirato, Tetrahedron Lett., 26, 6081 (1985).

25. H. Kise, H. Shirato, and H. Noritomi, Bull. Chem. Soc. Jpn., 60, 3613 (1987).

26. H. Kise and H. Shirato, Enzyme Microb. Technol., 10, 582 (1988).

27. H. Noritomi and H. Kise, Biotechnol. Lett., 9, 383 (1987).

28. H. Kise, K. Fujimoto, and H. Noritomi, $J$. Biotechnol., 8, 279 (1988).

29. G. Manecke and H.-G. Vogt, Makromol. Chem., 177, 725 (1976).

30. G. Manecke and H.-G. Vogt, Angew. Makromol. Chem., 78, 21 (1979).
31. H. Maeda, H. Suzuki, and A. Yamauchi, Biotechnol. Bioeng., 15, 607 (1973).

32. H. Maeda, H. Suzuki, and A. Yamauchi, Biotechnol. Bioeng., 15, 827 (1973).

33. K. Ichimura and S. Watanabe, J. Polym. Sci., Polym. Chem. Ed., 18, 891 (1980).

34. K. Ichimura, J. Polym. Sci., Polym. Chem. Ed., 22, 2817 (1984).

35. K. Imai, T. Shiomi, K. Sato, and A. Fujishima, Biotechnol. Bioeng., 25, 613 (1983).

36. K. Imai, T. Shiomi, K. Uchida, and M. Miya, Biotechnol. Bioeng., 28, 1721 (1986).

37. A. R. Fersht, D. M. Blow, and J. Fastrez, Biochemistry, 12, 2035 (1973). 